\title{
META A FIXAR
}

Na graduação de enfermeiros para todas as grandes Regiões do Brasil. poder-se-ia adotar a meta de nestes próximos cinco anos dobrar o número atual de concluintes. Os vestibulares nos grandes centros mostraram aumento encorajador de escolha da profissão de enfermagem. As primeiras opções para enfermagem são em número alto. Devemos conhecer e divulgar estes números.

Devem ter sido menos de 700 o número de graduados no País nos cursos de enfermagem, inclusive nas habilitações de obstetrícia, em 1972. O mercado de trabalho deve estar com capacidade de absorção do dobro desse número.

A profissão de enfermeiro figura entre as dez profissões técnico-científicas postas em prioridade em 1974, pelos órgãos competentes que traçam a política de tecnologia e trabalho no País. Compete à Associação Brasileira de Enfermagem, órgão cultural da classe, preparar um memorial que, aprovado pelos órgãos competentes - Conselho Federal de Educação e Departamento de Assuntos Universitários - Órgão de Planejamento e Coordenação Geral - possa apontar as providências recomendáveis para possivelmente dobrarse $o$ número atual de graduados em enfermagem.

Fim julho de 1972, o Governo Federal recebeu com aplauso da Comissão do Ensino Médico no Brasil seu Documento n.o 01, intitulado "A expansão da Rede Escolar". Consta desse documento o seguinte: "A Comissão entende que as providências no sentido do aprimoramento na formação de médicos e da melhoria de sua distribuição nas diferentes regiões e segmentos da população brasileira não surtirão pleno efeito sem que paralelamente se estimule, com o maior vigor, o preparo e o aproveitamento do pessoal de saúde, cuja deficiência é alarmante, qualquer que seja o termo da comparação utilizado".

O Diretor do DAU, acima citado, teve intenção de designar comissão de ensino de enfermagem. Em comissão oficial, ou em sua própria Associação de classe, enfermeiras escolhidas pela Diretoria desta última poderão elaborar o estudo que se faz necessário, com urgência, para atender-se ao que de nós espera o País. (RGD) 